\title{
Al-Qasamah: Alternatif Pembuktian Tindak Pidana Pembunuhan Dalam Hukum Positif
}

\author{
Islamul Haq \\ Institut Agama Islam Negeri Parepare \\ Email : islamulhaq@iainpare.ac.id
}

\begin{abstract}
This study aims to determine the extent of the legal force of the al-qasamah verification method, so that the verification method can be offered as an alternative proof of law in murder criminal cases where there are no witnesses and the culprit is unknown. This study uses a descriptive analysis method derived from sources related to Islamic criminal law. From the discussion it is known that, the method of proof of al-qasamah is one of the methods of proof that its existence and application are recognized in Islamic criminal law, even though the method originates from pre-Islamic jahiliyah times. Islamic Wisdom recognizes the method of proving al-qasamah is in order to protect, protect, and respect the human soul. With this method of proof, it is expected that victims of murder who have no witnesses, or who have not known the perpetrators, will not be ignored. This method of proving al-qasamah can be an alternative for proof in positive law, bearing in mind that the number of evidentiary criminal cases in Indonesia is not identified.
\end{abstract}

Keywords: Al-Qasamah, Proof, Criminal Murder.

\begin{abstract}
Abstrak
Penelitian ini bertujuan untuk mengetahui sejauh mana kekuatan hukum dari metode pembuktian al-qasamah, sehingga metode pembuktian tersebut dapat ditawarkan menjadi alternatif pembuktian hukum dalam kasus pidana pembunuhan yang tidak ada saksi dan tidak diketahui pelakunya. Penelitian ini menggunakan metode analisis dekstriftif yang berasal dari sumbersumber yang berhubungan Hukum Pidana Islam. Dari pembahasan yang ada diketahui bahwa, metode pembuktian al-qasamah merupakan salah satu metode pembuktian yang eksistentsi dan penerapannya diakui dalam Hukum Pidana Islam, meskipun metode tersebut berasal dari zaman jahiliyah pra islam. Hikmah Islam mengakui metode pembuktian al-qasamah adalah dalam rangka menjaga, melindungi, dan menghargai jiwa manusia. Dengan metode pembuktian ini diharapkan korban pembunuhan yang tidak ada saksinya, atau tidak diketahui pelakunya tidak terabaikan haknya begitu saja. Metode pembuktian al-qasamah ini bisa menjadi alternatif bagi
\end{abstract}




\section{Al-Qasamah}

pembuktian dalam hukum positif, mengingat banyaknya kasus tindak pidana pembuktian di Indonesia pelakunya tidak teridentifikasi.

Kata kunci: Al-Qasamah, Pembuktian, Pidana Pembunuhan.

\section{Istinbath: Jurnal Hukum}

Website : http://e-journal.metrouniv.ac.id/index.php/istinbath/index

Received : 2020-04-09| Reviewed : 2020-06-1| Published : 2020-06-7.

(c) (1) (2) This is an open access article distributed under the terms of the Creative Commons Attribution 4.0 International License, which permits unrestricted use, distribution, and reproduction in any medium, provided the original work is properly cited.

\section{Pendahuluan}

Tindak pidana pembunuhan atau dikenal dengan sebutan al-jinayah 'ala an-nafs al-insaniyyyah di dalam fiqh merupakan salah satu tindak pidana yang marak terjadi. Pembunuhan adalah "perbuatan menghilangkan nyawa seseorang"1. Menurut Wahbah Al-Zuhaili Pembunuhan adalah "perbuatan menghilangkan nyawa seseorang oleh orang lain yang menyebabkan tidak berfungisnya semua organ vital seseorang dan berpisahnya antara jasad dan roh".

Secara normatif, bila merujuk kepada "Undang-Undang RI Nomor 26 Tahun 2000 Tentang Pengadilan HAM", setidaknya ada sepuluh tindakan pelanggaran HAM, yang bisa diklasifikasikan sebegai bentuk kejahatan atas kemanusiaan yaitu Pembunuhan, slavery/perbudakan, genosida/Pemusnahan, Pengusiran, penjajahan/merampas kemerdekaan seseorang, Penyiksaan, Pemerkosaan, kekerasan dan penganiayaan yang didasari oleh politik dan SARA pada orang dan atau kelompok tertentu, penculikan, Kejahatan apartheid. ${ }^{2}$ Dengan kata lain berdasarkan undangundang HAM, maka tindak pidana pembunuhan adalah bagian dari tindakan kejahatan atas kemanusiaan.

\footnotetext{
${ }^{1}$ Abdul Qadir Audah, "al-Tasyri'al-jinai al-islami: Muqaranah bi al-Qanun al-Wadi'i," Beirut: Muassasah al-Risalah 2 (1992): 6.

${ }^{2}$ Mahmudi, “Analisi Fikih Jinayah Terhadap Kejahatan Kemanusiaan," Al-Qānūn Vol. 18, no. No. 2 (Desember 2015).
} 
Dalam kasus tindak pidana pembunuhan, tidak sedikit yang pelakunya belum diketahui sehingga proses penyelidikan menghabiskan waktu yang cukup lama, hal ini terjadi karena tidak adanya saksi dan kurangnya bukti sehingga pihak yang berwenang kesuliatan dalam menguak tindak pidana tersebut. Salah satu kasus yang cukup menyita perhatian publik yaitu pembunuhan Tri Ari Yani mahasiswi Universitas Esa Unggul yang ditemukan meninggal bersimbah darah di kamar kosnya di Komplek Kebon Jeruk Jakarta Barat pada hari Senin (9/1/2017) lalu. Sampai saat ini pihak kepolisian masih kesulitan menemukan pelaku karena tidak adanya saksi yang melihat langsung kejadian tersebut. Dan masih banyak lagi kasus-kasus pembunuhan yang pelakunya belum dapat diidentifikasi oleh pihak kepolisian.

Islam merupakan agama yang sangat menjaga dan menghargai nyawa manusia, bahkan jiwa (nyawa) menusia berada peda derajat yang sangat tinggi dalam Islam, hal ini dipertegas di dalam hadist yang diriwayatkan oleh sahabat Abdullah bin Masud bahwa Rasulullah SAW. Bersabda:

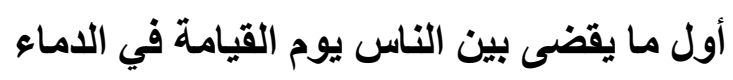

Artinya:

"perkara yang paling pertama diadili di antara manusia pada hari kiamat adalha masalah pertumpahan darah."

Rasulullah SAW. Memperlakukan jiwa manusia dengan penuh penghormatan, bahkan bukan hanya terbatas pada jiwa seorang muslim beliau memberikan penghormatan sampai kepada orang-orang Yahudi, sebgaiamana yang disebutkan oleh Imam Muslim dalam hadist yang diriwayatkan oleh Abu Laila, bahwa Qais bin saad dan sahal bin Hunaif berada di Qadisiah, kemudia tiba-tiba melintas di hadapan mereka seorang jenazah, lalu mereka berdiri. Kemudian mereka ditegur bahwa sesungguhnya jenazah itu ialah seorang majusi yang berasal dari Persia. Lalu mereka menjawab “ sesungguhnya Rasulullah SAW. Pernah berdiri ketika jenazah melintas dihadapan beliau, kemudian dikatakan kepada baliau "jenazah itu seorang Yahudi." Lalu beliau menjawab "Bukankah ia seorang jiwa?". Kedua hadist ini menunjukkan betapa besar penghormatan Islam terhadap jiwa manusia ${ }^{3}$. Oleh karena ituImam As-Syatibi di dalam

\footnotetext{
${ }^{3}$ Raghib As-sirjani, Nabi Sang Penyayang (Jakarta: Pustaka Al-Kautsar, 2017).
} 


\section{Al-Qasamah}

kitab al-Muwafaqat menjadikan salah satu maqashid als-yari'ah adalah hifzu al-nafs yang bermakna penjagaan terhadap jiwa (nyawa) ${ }^{4}$.

Dalam rangka menjaga jiwa ini maka aturan yang Allah berikan pada kasus pembunuhan adalah qisas, mekipun kemudian muncul banyak pendapat pakar hukum islam tentang mekanisme hukum qisas tersebut, yang didalamnya tentu terdapat nilainilai keadilan yang patut dipertimbangkan, karena didalamnya terdapat unsur keMahaadilan Tuhan dan pasti bermuara pada kemaslahatan manusia. ${ }^{5}$ Selain itu karena Allah SWT melalui ajaran Islam memberikan pernghormatan yang sangat tinggi terhadap jiw, maka dalam kondisi seperti apapun tindak pidana pembunuhan harus diselesaikan, bahkan dalam kasus pembunuhan yang sulit untuk diidentifikasi tidak adanya saksi. Salah satu solusi dalam Islam untuk menyelesaikan kasus pembunuhan yang tidak ada saksi dan pengakuan adalah al-qasamah.

Dalam Hukum Pidana Islam, terdapat empat bentuk pembuktian tindak pidana pembunuhan yaitu: pengakuan (iqrar), persaksian (syahadah), bukti atau indikator, sumpah (al-qasamah). Dari emapt macam pembuktian tersebut yang menarik untuk dikaji adalah pembuktian Al qasamah, dapat dideskripsikan sebagai pembuktian pada tindak pidana pembunuhan yang tidak diketahui pembunuhnya. Interpretasi seperti ini kemudian digunakan untuk proses pengambilan sumpah terhadap sebuah kelompok yang dicurigai melakukan pembunuhan atau karena adanya pembunuh di dalam kelompok tersebut ${ }^{6}$.

Pada awalnya, pembuktian al-qasamah dalam tindak pidana pembunuhan merupakan salah satu pembuktian pada masa jahiliah, akan tetapi karena pembuktian ini dianggap dapat menjadi alternatif dalam menyelesaikan tindak pidana pambunuhan terutama yang pelakunya tidak diketahui. Tentu menarik bila dikaji lebih mendalam, guna mengetahui lebih lanjut bagaimana penerapan dari al-qasamah ini dan bagaimana tatacar penerapan dari al-qasamah pada saat terjadi kasus pembunuhan yang tidak diketahui pembunuhnya?.

\footnotetext{
${ }^{4} \mathrm{Abu}$ Ishaq Al-Syatibi, “al-Muwafaqat fi Ushul al-Syari'ah,” Vol. II (Beirut: Dar al Kutub al Ilmiyah, $t t), 2003$.

${ }^{5}$ Muh Tahmid Nur, "Kontekstualisasi Keadilan Dalam Hukum Qisas," Al AHKAM: Jurnal Kajian IImu Hukum dan Syariah Vol. 1, no. No. 3 (2012): 18.

'Sayyid Sabiq, "Fiqh al-Sunnah, juz I," Beirut: Dar al-Fikr, 1981, 583.
} 


\section{Pembahasan}

\section{Sistem pembuktian dalam pidana umum dan pidana islam}

Perbedaan mendasar antara hukum islam dan hukum umum adalah sifat transenden. Dalam persprektif hukum umum, segala bentuk aturan yang sifatnya normatif materil dan formil memiliki pijakan pemikiran yang bersumber dari ide yang tersimpan dalam akal pikiran manusia. Dengan kata lain nilai ideal tersebut muncul berdasarkan pemikiran manusia tentang apa saja yang dianggap buruk dan apa saja yang dianggap buruk. Sehingga hukum yang menjadi norma, pengatur utama, mulai dari hak mendasar yang dimiliki manusia sebagai individu sampai pada sesuatu yang berada diluar hak dasar manusia, memiliki sifat yang antroposentris, Artinya menafikkan segala sesuatu yang berada diluar pikiran dan penalaran manusia. Selain itu orientasinya adalah mencapai keadilan dan kebenaran yang sifatnya duniawi saja, dengan kata lain kebenaran dan keadilan itu sebagaimana yang sudah disepakati adil dan benar menurut norma hukum umum. Kondisi tersebut berbanding terbalik dengan hukum islam. Hukum islam melandaskan hukumnya atas wahyu Allah SWT, dan juga sunnah/hadits Nabi SAW yang juga bersumber dari wahu Allah, sehingga hukum islam bersifat transenden dan teoantroposentris, dengan orientasi mencapai kebenaran dan keadilan multidmimensi, artinya kebenaran dan keadilan yang diputuskan oleh seseorang yang berwenang akan memiliki implikasi pertanggung jawaban di depan Tuhan. ${ }^{7}$

Setiap norma hukum yang diberlakukan, tentu memiliki nilai filosofis aksiologis, artinya setiap aturan itu secara filosofis pasti memiliki maksud dan tujuannya, termasuk dalam aturan pidana. Memhasa tentang tujuan ini, maka perlu diketahui bahwa terdapat lima tujuan utama dari aturan tentang tindak pidana adalah: retribution, deterrence, rehabilitation, incapacitation dan restoration. Sedangkan dalam sistem hukum nasional Indonesia, pemidanaan yang diatur dalam KUHP, memiliki masksud dan tujuan untuk pembalasan dan prevensi. Adapun diluar itu, maka pemidanaan bertujuan unutk memberikan perlindungan, dan kesejahteraan bagi masyarakat. Hal ini sedikit berbeda dengan Tujuan Pemidanaan yang adalah dalam sistem pidana islam. Dalam pidana islam/Fiqih Jinayat, tujuan dari adanya jinayah/hukum pidana adalah untuk pembalasan, rehabilitasi, pencegahan, dan

${ }^{7}$ Danial, “Qanun Jinayah Dan Perlindungan HAM," Al-manahij Jurnal Kajian Hukum Islam Vol. VI, no. No. 1 (Januari 2012): 85-98. 


\section{Al-Qasamah}

restorasi. ${ }^{8}$ Selain itu, Yang perlu diperhatikan secara seksama adalah, bahwa penerapan Pidana Islam/Jinayah (Qisas, diyat, dll), baik oleh rakyat ataupun negara, sebenarnya merupakan bentuk penegakan hukum terhadap jarimah jinayah yang menggunakan perspektif usul fiqih dan al-fiqh, dengan tidak mengabaikan metodologi dalam kajian siyasah al-syar'iyyah dan taqnin. Karena kedua metodologi ini saling berkaitan satu sama lain dalam melahirkan sebuah ketentuan/aturan jinayah. ${ }^{9}$

Bila merujuk kepada KUHP, maka akan ditemukan bahwa dalam "Pasal 104 sampai dengan Pasal 488" dijelaskan tentang macam-macam bentuk dan jenis tindakan kejahatan. Salah satu tindakan kejahatan yang paling ditakuti namun banyak sekali terjadi, adalah kejahatan pembunuhan, dan secara historis pembunuhan adalah bentuk tindak kejahata pertama yang dilakukan oleh anak adam/manusia. Tindak kejahatan ini telah diataur dalam "Pasal 338 KUHP yang berbunyi : Barang siapa dengan sengaja merampas nyawa orang lain, diancam karena pembunuhan dengan pidana penjara paling lama lima belas tahun". ${ }^{1011}$

Berkenaan dengan tindak kejahatan pembunuhan ini, dalam proses peradilannya tentu ada prosedur yang harus dilakuan untuk meyakinkan hakim bahwa seseorang itu benar-benar melakukan pidana pembunuhan, dan sebagaimana lazimnya penangan kasus pidana, maka harus ada alat bukti yang diajukan kepada hakim yang menangani perkara tersebut. Ada banyak sekali bentuk alat bukti yang bisa diajukan, dan berkenaan dengan alat bukti yang bisa digunakan dan diajukan sebagai bukti dalam perkara pidana pembunuhan antara lain adalah, keterangan yang diperoleh dari saksi, ahli, surat, petunjuk JPU, serta keterangan terdakwa. ${ }^{12}$ Jadi, bila seseorang diyakini telah melakukan pidana pembunuhan, maka yang menuduh harus bisa memberikan bukti

\footnotetext{
${ }^{8}$ Nafi' Mubarok, "Tujuan Pemidanaan dalam Hukum Pidana Nasional dan Fiqh Jinayah" 18, no. 2 (2015): 28.

${ }^{9}$ Nasrullah Yahya, "Legislasi Hukum Oositif (Fikih) Aceh: tinjauan pergumulan Qanun Hukum Jinayah," Ijtihad, Jurnal Wacana Hukum Islam dan Kemanusiaan Vol. 14, no. No. 2 (Desember 2014): 149-66.

10 Salvadoris Pieter dan Erni Dwita Silambi, "Pembuktian Dalam Tindak Pidana Pembunuhan Berencana Ditinjau Dari Kitab Udang-Undang Hukum Pidana," Jurnal Restorative Justice 3, no. 1 (30 Mei 2019): 75-91.

11 Nurul Husna, "Hukum Jinayah Antara Aplikasi Dan Sejarah," LEEGALITEE. Jurnal Perundang Undangan dan Hukum Pidana Islam Vol. II, no. 01 (Juni 2017): 21.

12 Endah Tresyani, "Pelaksanaan Pembuktian Tindak Pidana Pembunuhan Berencana Di Persidangan Oleh Penuntut Umum Kejaksanaan Negeri Surakarta," Jurnal Verstek Vol. 2, No. No. 2 (2014): 12.
} 
yang dapat memperkuat tuduhannya dalam proses persidangan baik itu yang berupa persaksian, ketertangan dan lain sebagainya.

Dalam ajaran Islam seberanya telah ada semacam "Kitab Undang-Undang Hukum Pidana (KUHP)" versi hukum Islam, yang menjadi social tools ajaran Islam dalam merespon semua bentuk perkembangan hukum dan tindak kejahatan dalam masyarakat yang selalu dinamis dan berubah. Meskipun secara hukum normatif KUHP versi islam memanglah belum ada, akan tetapai bila kita coba melakukan kajian dan penelusurian dalam kitab-kitab fiqih klasik maupun kontemporer tetang pidana/jinayah, niscaya akan kita temukan dalam ajaran islam terdapat syari'at al-'uzma (hukum utama), yang berkaitan dengan hukum pidana dan diintisarikan dari nash-nash dalam alQur'an. Secara literasi, kajian utama fiqih jinayah adalah unsur-unsur jinayah itu sendiri, yang terdiri dari :

1. Al-Ruknu Al-Syar'i (Asas Legalitas) atau unsur hukum materil. Merupakan unsur dasar hukum dari nash atau ayat al-qur'an, yang secara eskplisit memberikan aturan-aturan tertentu tentang suatu perbuatan tertentu, yang disertai ancaman 'azab bila melakukan dan atau melanggarnya;

2. Al-Ruknu Al-Madi (Unsur bukti), yaitu unsur yang menjadi petunjuk dan atau indikasi, bahwa benar seseorang yang dituduh melakukan melakukan suatu perbuatan pidana, atau meninggalkan suatu perbuatan yang harusnya dilakukan.

3. Al-Ruknu Al-Adabi (unsur pelaku), yaitu unsur pidana yang berkaitan dengan pelaku pidana, yang harus termasuk kedalam kelompok orang yang bisa dikategorikan sebagai subjek/pelaku dan bisa menjadi objek pidana/tersangka dan atau terdakwa. Denga kata lain pelaku tidak boleh termasuk kedalam kelompok orang yang berada dibawah pengampuan. ${ }^{13}$

Dari poin kedua, dapat kita ketahui bahwa pembuktian dalam pidana Islam/Jinayah dapat dilakukan dengan menunjukkan unsur yang memberikan petunjuk dan atau indikasi yang jelas tentang siapa yang dijadikan tersangka pembunuhan. Namun terkadang pembuktian menjadi terkendala bila kemudian tidak didapati petunjuk apapun, misalnya berkenaan dengan kasus pembunuhan, sehingga dibutuhkan suatu

13 Hendra Gunawan, “Kitab Undang-Undang Fikih Jinayah (KUFJ),” Jurnal El-Qanuny VOI. 3, no. No. 2 (2017): 14. 


\section{Al-Qasamah}

formula yang bisa memberikan jalan keluar bila terjadi kasus-kasus pembunuhan yang kekurangan bukti.

\section{Alqasamah Sebagai Alat Bukti Dalam Kasus Pembunuhan}

Dalam sistem pembuktian pidana umum, saksi merupakan salah satu alat bukti yang sah. Selain itu dalam pidana umum, dikenal istilah saksi mahkota, yang dapat menjadi bukti atas suatu tindak pidana pembunuhan yang kekurangan alat bukti. Meskipun eksistensinya tidak pernah disebutkan dalam KUHAP secara eksplisit dan tegas, tetapi dalam prakteknya saksi mahkota ini sering dihadirkan oleh Jaksa Penuntut Umum sebagai alat bukti saksi. Kedudukan sebanding dengan saksi-saksi lainnya dan merupakan bagian dari alat bukti yang sah, selama memenuhi syarat-syarat diajukannya saksi dalam proses pembuktiannya dan bergantung pada bagaiamana hakim menimbang dan menilai tentang syarat formil dan materiil diajukannya saksi tersebut, serta relevansinya dengan alat bukti yang lain. ${ }^{14}$ Demikian dalam hukum Islam bila terjadi suatu kasus pembunuhan, akan tetapi keterangan dan petunjuk yang berkaitan dengan kasus tersebut kurang, maka dalam pidana Islam dapat diberlakukan suatu ketentuan pembuktian yang disebut dengan al-qasamah yang notabene merupakan pembuktian pada zaman jahiliyah namun tetap diakomodir oleh ajaran Islam demi melindungi jiwa manusia, supaya korban pembunuhan yang tidak bukti dan atau saksinya tidak terabaikan begitu saja.

\section{Pengertian Al-Qasamah}

Qasamah(القسامة) menurut Bahasa merupakan masdar dari kata (قسم) yang berarti (bagus dan indah). Imam Haramain menceritakan bahwa qasamah menurut fuqaha adalah nama untuk sumpah; dan menurut ahli Bahasa adalah nama untuk orang yang bersumpah. Di dalam kitab mu'jam al lugah disebutkan bahwa qasamah adalah sumpah yang diucapkan penduduk setempat (tempat ditemukannya korban pembunuhan $)^{15}$.

Secara terminology, al-qasamah didefenisikan oleh Ibnu Nujaim sebagai sumpah yang diucapkan oleh penduduk tempat ditemukannya korban pembunuhan

14 Hajairin, "Konstruksi Hukum Dalam Pembuktian Unsur Tindak Pidana Pembunuhan Berencana," Sangaji: Jurnal Pemikiran Syariah dan Hukum Vol. I, no. No. 1 (Maret 2017): 59-70.

${ }^{15}$ Muhammad Rawas dan Hamid Shadiq, Mu'jam al-Lughah al-Fuqaha, Jordan: Dar al-Nafa'is (Jordan, 1985). 
setiap mereka mengucapkan "wallahi (demi Allah) saya tidak membunuhnya dan tidak mengetahui tentang pembunuhannya."16 Menurut Jamaluddin Al-Rumi al-qasamah adalah sumpah yang diucapkan oleh penduduk sebuah kampung atau desa tempat ditemukannya korban pembunuhan setiap penduduk mengucapkan sumpah "demi Allah saya tidak membunuhnya dan saya tidak mengetahui tentang pembunuhannya." ${ }^{17}$ Ibnu Rusyd mendefenisikan al-aqasamah sebagai sumpah yang diulang-ulang dalam tuntutan pembunuhan yaitu sumpah yang diucapkan sebanyak lima puluh sumpah dari keluraga (wali) korban,sumpah tersebut juga diucapkan oleh limapuluh penduduk tempat ditemukannya korbayang dipilih oleh wali darah, untuk menyangkal tuduhan pembunuhan, dengan cara mengucapkan sumpah, "Demi Allah, saya tidak membunuhnya dan tidak mengetahui pelaku"18

Dakwaan al-qasamah berbeda dengan dakwaan-dakwaan lainnya, dia antara perbedaannya adalah pertama, alqasamah sebenarnya merupakan sumpah yang diarahkan kepada orang yang menuduh, sementara dakwaan-dakwaan yang lain, bukti diarahkan kepada yang menuduh dan sumpah bagi orang yang dituduh sesuai dengan hadist Nabi dari Abdullah bin Abbas Rasulllah SAW. Bersabda:

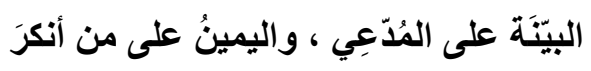

Artinya: bagi pendakwa atau penuduh wajib mendatangkan bukti dan bagi yang tertuduh harus bersumpah jika dia mengingkari.Kedua, sumpah alqasamahdilakukan secara berulang-ulang sementara dalam dakwaan yang lainnya hanya dilakukan satu kali sumpah.

Menurut jumhur, yang mengucapkan sumpah al-qasamah adalah para wali korban untuk menguatkan tuduhan pembunuhan tehadap pelaku, jika terdapat sebagian dari korban yang tidak bersedia untuk bersumpah, maka wali lainnya yang mengambilalih sumpah sebagian mereka yang tidak bersedia bersumpah sehingga genap limapuluh sumpah, dan diyat yang menjadi haknya diberikan kepada wali korban yang bersedia untuk bersumpah. Apabila tidak ada satupun dari wali korban yang bersedia

\footnotetext{
${ }^{16}$ Zainuddin bin Nujaim, Al-Bahru Ar-Raiq Syarah Kanzu Ad-Daqaiq (Beirut: Dar al-Marifah, tt, t.t.).

17Jamaluddin Al-Rumi, Al-Inayah Syarh Al-Hidayah (Beirut: Dar Al-Fikr, t.t.).

${ }^{18} \mathrm{Ibn}$ Rusyd, Bidayah al-Mujtahid wa Nihayah al-Muqtashid, terj. Imam Ghazali Said dan Achmad Zaidun, Bidayatul Mujtahid: Analisa Fiqih Para Mujtahid, t.t.
} 


\section{Al-Qasamah}

untuk bersumpah dan di tempat kejadian ditemukan laus, yaitu indikasi yang menunjukkan tentang kebenaran tindak pembunuhan atau terdapat permusuhan yang nyata antara horban dan yang tertuduh, maka pihak wali yang tertuduh diminta untuk bersumpah sebanyak lima puluh kali dalam rangka menyangkal tuduhan yang ada. Jika tertuduh tidak mempunyai wali (keluarga) maka si tertuduh diminta untuk bersumpah sebanyak lima puluh kali ${ }^{19}$.

Jadi, jika ditemukan korban pembunuhan yang tidak diketahui siapa pembnuhnya, tetapi terdapa beberapa indicator mengenai pembunuhnya, baik indicator berupa permusuhan yang terjadi di antara korban dan yang tertuduh atau korban ditemukan di tempat tertuduh atau barang bukti pembunuhan ditemukan pada orang yang tertuduh, maka keluarga korban harus bersumpah sebanyak lima puluh kali atas ketetapan dan keabsahan dakwaan mereka. Apabila yang tertuduh mengingkari tuduhan, maka dia harus bersumpah sebanyak lima puluh kali supaya dia bebas. Dan apabila dia mengingkari kembali maka hukum ditetapkan bedasarkan pengingkaran tersebut ${ }^{20}$.

Apabila para wali korban telah mengucapkan sumpah al-qasamah, dan tertuduh tidak mau bersumpahatau tidak mengingkari tuduhan,makavonis hukumnya adalah qisas jika ia melakukan pembunuhan dengan sengaja dan denda berupa diyat jika kasus pembunuhannya semi sengaja atau tersalah. Adapun pendapat yang masyhur dalam mazhab hukumannya adalah membayar diyat, dalam bentuk pembunuhan apapun sengaja, semu sengaja maupun tersalah. Sementara dalam mazhab Hanabilah, hukumnya adalah qisas jika pembunuhan sengaja, dan membayar diyat jika pembunuhan semi sengaja atau tersalah.

\section{Alqasamah Sebagai Alat Bukti Dalam Kasus Pembunuhan}

Dalam sistem pembuktian pidana umum, saksi merupakan salah satu alat bukti yang sah. Selain itu dalam pidana umum, dikenal istilah saksi mahkota, yang dapat menjadi bukti atas suatu tindak pidana pembunuhan yang kekurangan alat bukti. Meskipun eksistensinya tidak pernah disebutkan dalam KUHAP secara eksplisit dan tegas, tetapi dalam prakteknya saksi mahkota ini sering dihadirkan oleh Jaksa Penuntut Umum sebagai alat bukti saksi. Kedudukan sebanding dengan saksi-saksi lainnya dan

\footnotetext{
${ }^{19}$ Mustafa Al-Khin, al-Fiqh al-Manhaji 'ala Madhhab al-Imam al-Shafi 'i, j. 2 dan 3, Damshiq: Dar al-Qalam, 2008.

${ }^{20}$ Abdullah bin Abdurrahman Al Bassam dkk., Syarah bulughul maram (Pustaka Azzam, 2006).
} 
merupakan bagian dari alat bukti yang sah, selama memenuhi syarat-syarat diajukannya saksi dalam proses pembuktiannya dan bergantung pada bagaiamana hakim menimbang dan menilai tentang syarat formil dan materiil diajukannya saksi tersebut, serta relevansinya dengan alat bukti yang lain. ${ }^{21}$ Demikian dalam hukum Islam bila terjadi suatu kasus pembunuhan, akan tetapi keterangan dan petunjuk yang berkaitan dengan kasus tersebut kurang, maka dalam pidana Islam dapat diberlakukan suatu ketentuan pembuktian yang disebut dengan al-qasamah yang notabene merupakan pembuktian pada zaman jahiliyah namun tetap diakomodir oleh ajaran Islam demi melindungi jiwa manusia, supaya korban pembunuhan yang tidak bukti dan atau saksinya tidak terabaikan begitu saja.

\section{Pengertian Al-Qasamah}

Qasamah(القسامة) menurut Bahasa merupakan masdar dari kata (قسم) yang berarti الحسن والجمال (bagus dan indah). Imam Haramain menceritakan bahwa qasamah menurut fuqaha adalah nama untuk sumpah; dan menurut ahli Bahasa adalah nama untuk orang yang bersumpah. Di dalam kitab mu'jam al lugah disebutkan bahwa qasamah adalah sumpah yang diucapkan penduduk setempat (tempat ditemukannya korban pembunuhan $)^{22}$.

Secara terminology, al-qasamah didefenisikan oleh Ibnu Nujaim sebagai sumpah yang diucapkan oleh penduduk tempat ditemukannya korban pembunuhan setiap mereka mengucapkan "wallahi (demi Allah) saya tidak membunuhnya dan tidak mengetahui tentang pembunuhannya." ${ }^{23}$ Menurut Jamaluddin Al-Rumi al-qasamah adalah sumpah yang diucapkan oleh penduduk sebuah kampung atau desa tempat ditemukannya korban pembunuhan setiap penduduk mengucapkan sumpah "demi Allah saya tidak membunuhnya dan saya tidak mengetahui tentang pembunuhannya." ${ }^{24}$ Ibnu Rusyd mendefenisikan al-aqasamah sebagai sumpah yang diulang-ulang dalam tuntutan pembunuhan yaitu sumpah yang diucapkan sebanyak lima puluh sumpah dari keluraga (wali) korban,sumpah tersebut juga diucapkan oleh limapuluh penduduk tempat ditemukannya korbayang dipilih oleh wali darah, untuk menyangkal tuduhan

21 Hajairin, "Konstruksi Hukum Dalam Pembuktian Unsur Tindak Pidana Pembunuhan Berencana," Sangaji: Jurnal Pemikiran Syariah dan Hukum Vol. I, no. No. 1 (Maret 2017): 59-70.

${ }^{22}$ Muhammad Rawas dan Hamid Shadiq, Mu'jam al-Lughah al-Fuqaha, Jordan: Dar al-Nafa'is (Jordan, 1985).

${ }^{23}$ Zainuddin bin Nujaim, Al-Bahru Ar-Raiq Syarah Kanzu Ad-Daqaiq (Beirut: Dar al-Marifah, tt, t.t.).

${ }^{24}$ Jamaluddin Al-Rumi, Al-Inayah Syarh Al-Hidayah (Beirut: Dar Al-Fikr, t.t.). 


\section{Al-Qasamah}

pembunuhan, dengan cara mengucapkan sumpah, "Demi Allah, saya tidak membunuhnya dan tidak mengetahui pelaku"25

Dakwaan al-qasamah berbeda dengan dakwaan-dakwaan lainnya, dia antara perbedaannya adalah pertama, alqasamah sebenarnya merupakan sumpah yang diarahkan kepada orang yang menuduh, sementara dakwaan-dakwaan yang lain, bukti diarahkan kepada yang menuduh dan sumpah bagi orang yang dituduh sesuai dengan hadist Nabi dari Abdullah bin Abbas Rasulllah SAW. Bersabda:

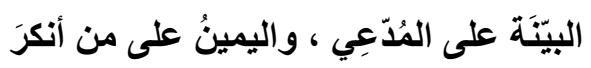

Artinya: bagi pendakwa atau penuduh wajib mendatangkan bukti dan bagi yang tertuduh harus bersumpah jika dia mengingkari.Kedua, sumpah alqasamahdilakukan secara berulang-ulang sementara dalam dakwaan yang lainnya hanya dilakukan satu kali sumpah.

Menurut jumhur, yang mengucapkan sumpah al-qasamah adalah para wali korban untuk menguatkan tuduhan pembunuhan tehadap pelaku, jika terdapat sebagian dari korban yang tidak bersedia untuk bersumpah, maka wali lainnya yang mengambilalih sumpah sebagian mereka yang tidak bersedia bersumpah sehingga genap limapuluh sumpah, dan diyat yang menjadi haknya diberikan kepada wali korban yang bersedia untuk bersumpah. Apabila tidak ada satupun dari wali korban yang bersedia untuk bersumpah dan di tempat kejadian ditemukan laus, yaitu indikasi yang menunjukkan tentang kebenaran tindak pembunuhan atau terdapat permusuhan yang nyata antara horban dan yang tertuduh, maka pihak wali yang tertuduh diminta untuk bersumpah sebanyak lima puluh kali dalam rangka menyangkal tuduhan yang ada. Jika tertuduh tidak mempunyai wali (keluarga) maka si tertuduh diminta untuk bersumpah sebanyak lima puluh $\mathrm{kali}^{26}$.

Jadi, jika ditemukan korban pembunuhan yang tidak diketahui siapa pembnuhnya, tetapi terdapa beberapa indicator mengenai pembunuhnya, baik indicator berupa permusuhan yang terjadi di antara korban dan yang tertuduh atau korban

\footnotetext{
${ }^{25}$ Ibn Rusyd, Bidayah al-Mujtahid wa Nihayah al-Muqtashid, terj. Imam Ghazali Said dan Achmad Zaidun, Bidayatul Mujtahid: Analisa Fiqih Para Mujtahid, t.t.

${ }^{26}$ Mustafa Al-Khin, al-Fiqh al-Manhaji 'ala Madhhab al-Imam al-Shafi 'i, j. 2 dan 3, Damshiq: Dar al-Qalam, 2008.
} 
ditemukan di tempat tertuduh atau barang bukti pembunuhan ditemukan pada orang yang tertuduh, maka keluarga korban harus bersumpah sebanyak lima puluh kali atas ketetapan dan keabsahan dakwaan mereka. Apabila yang tertuduh mengingkari tuduhan, maka dia harus bersumpah sebanyak lima puluh kali supaya dia bebas. Dan apabila dia mengingkari kembali maka hukum ditetapkan bedasarkan pengingkaran tersebut ${ }^{27}$.

Apabila para wali korban telah mengucapkan sumpah al-qasamah, dan tertuduh tidak mau bersumpahatau tidak mengingkari tuduhan,makavonis hukumnya adalah qisas jika ia melakukan pembunuhan dengan sengaja dan denda berupa diyat jika kasus pembunuhannya semi sengaja atau tersalah. Adapun pendapat yang masyhur dalam mazhab hukumannya adalah membayar diyat, dalam bentuk pembunuhan apapun sengaja, semu sengaja maupun tersalah. Sementara dalam mazhab Hanabilah, hukumnya adalah qisas jika pembunuhan sengaja, dan membayar diyat jika pembunuhan semi sengaja atau tersalah.

Pada awalnya, pembuktian al-qasamah dalam tindak pidana pembunuhan merupakan salah satu pembuktian pada masa jahiliah, akan tetapi karena pembuktian ini dianggap dapat menjadi alternatif dalam menyelesaikan tindak pidana pambunuhan terutama yang pelakunya tidak diketahui, maka Islam menggunakan bentuk pembuktian ini, hal tersebut dapat ditemukan di dalam beberapa hadist Nabi tentang al-qasamah di antaranya hadist riwayat Muslim dari Yahya dan Rafi bin Khadij:

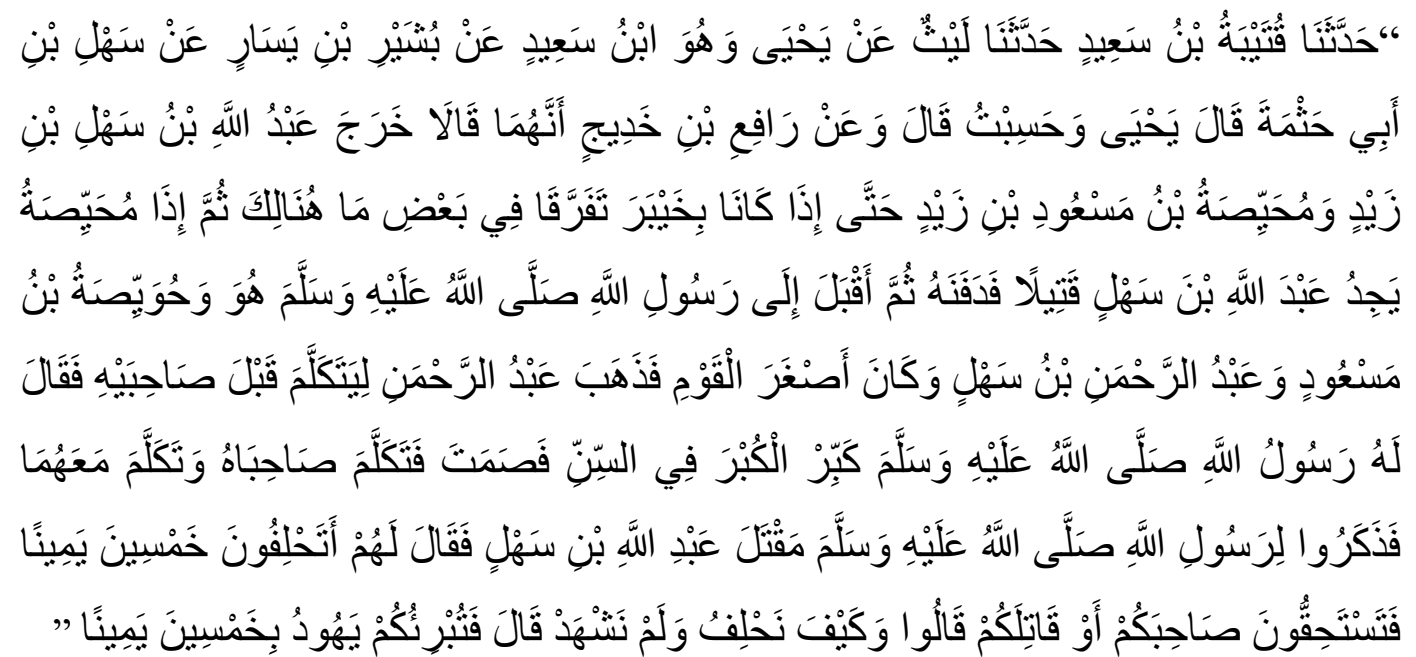

Artinya:

${ }^{27}$ Abdullah bin Abdurrahman Al Bassam dkk., Syarah bulughul maram (Pustaka Azzam, 2006). 
"Telah menceritakan kepada kami Qutaibah bin Sa'id telah menceritakan kepada kami Laits, dari Yahya(yaitu Ibnu Sa'id), dari Busyair bin Yasar, dari Sahal bin Abu Hatsmah-Yahya berkata: dan aku mengira dia berkata- dari Rafi' bin Khadij bahwa keduanya berkata, Abdullah bin Sahl bin Zaid dan Muhayishah bin Mas'ud bin Zaid pernah melakukan safar, hingga ketika mereka sampai di Khaibar, mereka berdua berpisah, Tidak beberapa lama Muhayishah mendapati Abdullah telah terbunuh, dia pun menguburkannya. Sesudah itu dia datang menghadap Rasulullah shallallahu 'alaihi wasallam bersama-sama dengan Huwaishah bin Mas'ud dan Abdurrahman bin Sahl. Sedangkan Abdurrahman adalah yang paling muda di antara mereka, tetapi Abdurrahman yang lebih dahulu berbicara daripada saudara sepupunya itu. Maka Rasulullah shallallahu 'alaihi wasallam bersabda: Dahulukanlah yang lebih tua umurnya. Maka ia pun diam dan kedua saudaranya lalu angkat bicara. Keduanya menceritakan kepada beliau bahwa Abdullah bin Sahal telah terbunuh, lalu Rasulullah shallallahu 'alaihi wasallam bertanya kepada mereka: Maukah kalian bersumpah lima puluh kali?, Jika kalian mau bersumpah, maka kalian berhak menuntut balas atas kematian saudara kalian. Mereka menjawab: Bagaimana kami harus bersumpah, sedangkan kami tidak menyaksikan terjadinya pembunuhan itu. Rasulullah shallallahu 'alaihi wasallam bersabda: Jika begitu maka orang-orang Yahudi akan bebas dari kalian dengan lima puluh sumpah yang mereka lakukan. Mereka menjawab: Bagaimana mungin kami dapat menerima sumpah orang kafir itu?, melihat kondisi seperti itu, akhirnya Rasulullah shallallahu 'alaihi wasallam memberikan diyatnya (tebusannya)."

Selain itu bentuk pengakuan pengakuan lain yang terdapat dalam keterangan hadis Rasulullah SAW, adalah hadis yang diriwayatkan oleh Imam Ahmad, Imam Muslim, dan Imam Al-Nasai dari Abu Salamah dan Sulaiman Ibn Yasar:

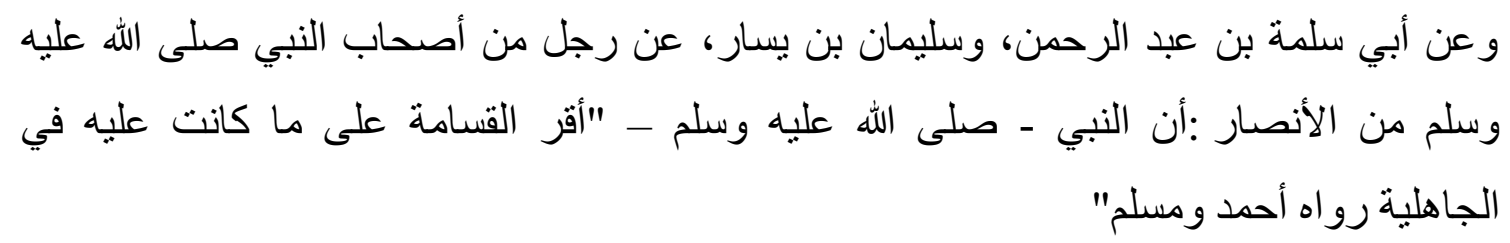


Artinya: "dari Abu Salamah ibn Abdurrahman dan Sulaiman bin Yasar dari seorang laki-laki sahabat Nabi dari kaum Anshar bahwasanya Rasulullah SAW. Menetapkan (mengakui) al-qasamah, sebagaimana yang pernah berlaku pada zaman jahiliyah."

Berdasarkan hadist di atas, mayoritas ulama fiqh yang terdiri dari fuqaha empat mazhab, zhahiriyah dan Syiah berpendapat bahwa al-qasamah merupakan alat bukti dalam tindak pidana pembunuhan yang diakui secara sah dalam Islam. ${ }^{28}$ Selain itu $a l$ qasamah ini sangat mungkin untuk dapat dijadikan alternatif dalam menyelesaikan tindak pidana pembunuhan yang pelakunya tidak diketahui. Karena diantara penyebab munculnya perselisihan pada kedua belah pihak adalah merasa tidak adanya solusi dalam pengusutan kasus pembunuhan. Pendapat jumhur yang menyatakan bolehnya menerapkan alqasamah diperkuat oleh hadist-hadist lain, yang membahas tentang Muhaishah dan Huwaishah, yang telah disebutkan pada pendahuluan. Selain itu, terdapat hadis lain yang peristiwanya mirip dengan peristiwa Muhaishah dan Huwaishah, dan hadis ini menjadi dasar hukum yang memperkuat argumentasi jumhur ulama tentang alqasamah. Imam Al Bukhari meriwayatkan:

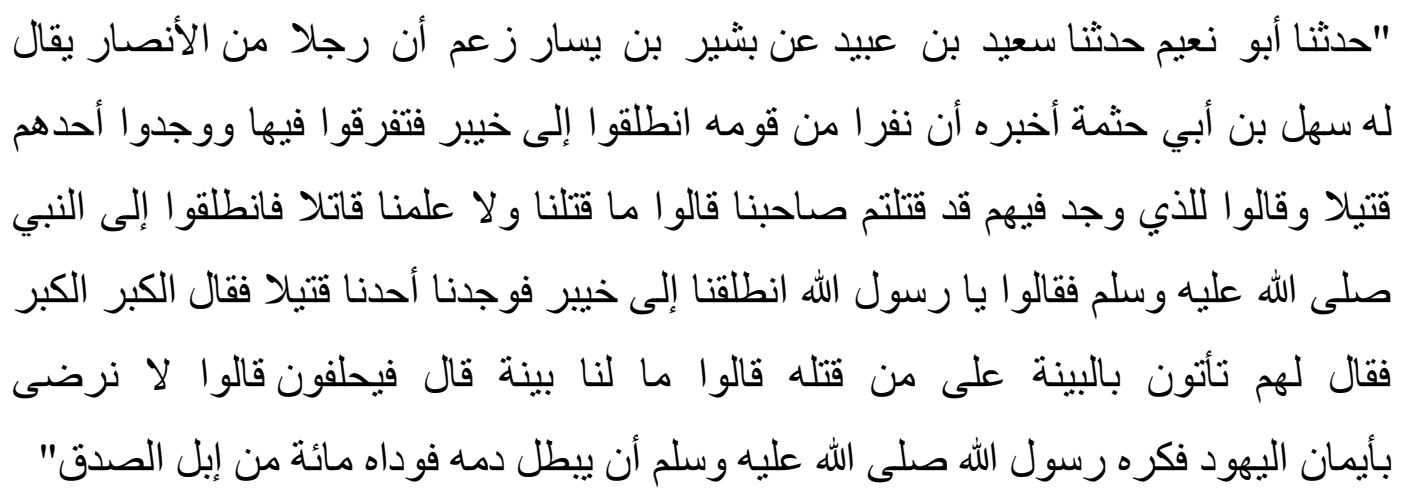

Artinya:

"telah menceritakan kepada kami Abu Na'im, Said bin Ubaid dan Basyar bin Yasar menceritakan bahwa sesungguhnya seorang laki-laki dari kaum Anshar yang bernama Sahal bin Abi Hatsmah menceritakan bahwa sekelompok orang dari kaumnya pergi ka Khaibar dan mereka terpisah di sana, lalu mereka menemukan salah seorang dari rombongan mereka mati terbunuh. Lalu mereka berkata kepada penduduk setempat kalian telah membunuh teman kami, mereka menjawab: kami tidak membunuhnya dan kami tidak tau pembunuhnya. Mereka kemudian berangkat dan menghadap Rasulullah SAW. Lalu mereka berkata kepada Rasulullah SAW : ya Rasulullah, Kami pergi ke Khaibar kemudian kami menemukan salah seorang teman kami terbunuh, Nabi berkata: bicaralah yang

${ }^{28}$ Wahbah Zuhaili, al-Fiqh al-Islamiyah Wa Adillatuh, Juz IV,(Suriah: Dar al-Fikr, 1989), 1989. 
paling tua umurnya di antara kalian, kemudian Nabi berkata kepada mereka: datanglah kalian dengan membawa saksi atas orang yang membunuhnya, mereka berkata: kami tidak mempunyai seorang saksipun. Nabi berkata: kalau begitu mereka harus bersumpah, mereka berkata: kami tidak suka dengan sumpah orang yahudi. Nabi tidak suka membatalkan qisasnya lalu Nabi membayarnya dengan seratus ekor unta yang diambil dari zakat."

Hadis-hadist yang telah disebutkan di atas, menunjukkan secara jelas bahwa alqasamah benar-benar digunakan sebagai salah satu metode pembuktian dalam tindak pidana pembunuhan yang tidak diketahui pelakunya dan tidak ada saksi dalam tindak pidana tersebut. Dan hadist-hadist yang telah disebutkan di atas merupakan hadisthadist sahih yang dapat dijadikan sebagai dasar hukum.

Sementara itu beberapa ulama lainnya seperti Abu Qilabah, Umar bin Abdul Aziz, Salim bin Abdullah berpendapat bahwa al-qasamah tidak dapat dijadikan sebagai alat bukti, mereka beralasan bahwa pembuktian al-qasamah bertentangan dengan prinsip-prinsip dasar hukum Islam diantarnya:

1. Menurut Syariat Islam, seorang muslim tidak boleh bersumpah kecuali tentang hal yang ia ketahui secara pasti dan ia saksikan dengan mata kepalanya sendiri. AlQasamah yang dilakukan oleh wali korban yang terbunuh tidak mengetahui dengan pasti dan tidak menyaksikan langsung peristiwa pembunuhan, hal ini tentu bertentangan dengan prinsip hukum Islam. Logika di atas sesuai dengan apa yang diriwayatkan oleh Imam Al-Bukhari :

"bahwasanya Abu Qilabah telah menceritakan bahwa Umar bin Abdul Aziz. suatu hari membuka singgasananya bagi rakyatnya, lalu beliau mengizinkan rakyatnya untuk masuk, lalu mereka masuk, Maka Umar ibn Abdul 'Aziz: berkata : bagaimana pendapat kalian tentang qasamah?, Abu Qilabah berkata: Kami menjawab tentang qasamah bahwa qishash dengan dasar qasamah adalah hak (benar), dan hal itu telah dilakukan oleh para Khalifah. Lalu Umar bin Abdul 'Aziz berkata kepadaku: Bagaimana pendapatmu hai Abu Qilabah. Engkaulah yang menggelar diskusi ini dengan mereka. Saya menjawab: Hai Amirul mukminin, anda memiliki prajurit dan pemimpin-pemimpin Arab, bagaimana pendapat anda, jika Lima puluh orang dari mereka menjadi saksi atas seorang laki-laki muhshan di Damaskus bahwa ia berzina tetapi mereka tidak melihatrrya, apakah anda akan merajamnya? la meniawab: Tidak. Saya 
berkata lagi: bagaimana pendapat anda, andai kata Lima puluh orang dari mereka menjadi saksi atas seorang laki-laki di Himisha tetapi mereka tidak melihatnya. Apakah anda akan memotong tangannya?, ia menjawab: Tidak. Saya berkata lagi: Demi Allah, Rasulullah SAW tidak menghukum bunuh seorang pun kecuali dalam salah satu dari tiga perkara, pertama seorang lakilaki yang membunuh karena menurutkan nafsunya, maka ia harus diqisas, kedua laki-laki yang berzina dalam keadaan ihsan, ketiga laki laki yang memerangi Allah dan Rasulnya dan keluar dari Islam".

2. Dalam Hukum Pidana Islam saksi merupakan hak penuntut, dan sumpah adalah hak tersangka. Tetapi dalam alqasamah justru sumpah terlebih dahulu dilakukan oleh penuntut (keluarga korban), maka tentu hal ini tidak sesuai dengan prinsip dalam Hukum Pidana Islam

3. Hadist yang dijadikan dasar bagi kelompok yang menerima al-qasamah, merupakan salah satu strategi Nabi dalam rangka memperlunak hukum untuk kemudian dihapuskan secara bertahap. Terlihat dari redaksi hadist-hadist tersebut yang bersifat penawaran kepada keluarga korban untuk bersumpah. Tetapi keluarga korban mempertanyakan sumpah tersebut karena mereka tidak menyaksikan peristiwanya, jika Sunnah mengharuskan bersumpa meskipun mereka tidak menyaksikan peristiwa, maka Nabi pasti menyatakan bahwa hal ini adalah Sunnah. Jika demikian maka yang lebih utama adalah kembali kepada prinsip pokok dalam syariat Islam sebagaimana yang telah diuraikan. Pendapat ini dijawab oleh ulama yang menerima alqasamah sebagai salah satu metode pembuktian. Menurut mereka hadist tentang alqasamah, merupakan hadist yang bersdiri sendiri dan dapat mekhususkan yang umum, sebagaimana hadist-hadist mukhashisah lainnya. Hadist tentang al qasamah merupakan hadist khusus sehingga tidak bisa dibatalkan dengan dalil yang bersifat umum. Dalam hal ini sebab diterimanya alqasamah adalah menjaga jiwa manusia ${ }^{29}$. Ketika pembunuhan bertambah marak dan saksi sangat minim, karena mungkin dilakukan di tempat yang sunyi, maka Sunnah menjadikan al qasamah sebagai salah satu metode pembuktian untuk memelihara jiwa yang hilang tanpa hak ${ }^{30}$.Kemudian

\footnotetext{
${ }^{29}$ Wardi Muslich, “Alat Bukti Dalam Tindak Pidana Pembunuhan,” Al-Qalam 11, no. 56 (1995): 47.

${ }^{30}$ Rusyd, Bidayah al-Mujtahid wa Nihayah al-Muqtashid, terj. Imam Ghazali Said dan Achmad Zaidun. 577
} 


\section{Al-Qasamah}

menurut As Syaukani pendapat fuqaha yang tidak menerima al-qasamah karena tidak sesuai prinsip pokok syariat,

Menurut penulis, metode pembuktian al-qasamah memang merupakan metode yang kontroversial, karena bertentangan dengan beberapa prinsip-prinsip yang ada di dalam syariat Islam. Akan tetapi di sisi lainnya dalam syariat Islam terdapat prinsip lain yang merupakan salah satu maqashid syariah kategori dhaririyat yaitu hifdzu al nafs $\left(\right.$ menjaga jiwa) ${ }^{31}$. Salah satu prinsip jaminan terhadap jiwa, jiwa manusia tidak boleh hilang begitu saja tanpa ada imbalan, metode pembuktian dengan al-qasamah merupakan salah satu metode yang patut dipertimbangkan, terlebih metode ini telah dimplementasikan pada zaman Rasulullah SAW., meskipun berasal dari zaman jahiliyah.

\section{Mekanisme Penerapan Al-Qasamah}

\section{Syarat-syarat al-Qasamah}

Dalam mekanisme penerapan suatu hukum, apalagi itu adalah hukum pidana islam/jinayah, tentu terdapat syarat-syarat yang harus diperhatikan sebelum melaksanakan keten-tuan tersebut, termasuk dalam sistem pembuktian al-qasamah. syarat-yarat al-qasamah yaitu ${ }^{32}$ :

1. Ada indikasi yang menunjukan kemungkinan terjadinya pembunuhan, misalnya ditemukannya pada tubuh korban luka bekaspukulan, tikaman, tebasan atau bekas cekikan, jika tidak ditemukan maka alqasamah tidak dapat diberlakukan begitupula dengan pembayaran diyat. Karena jika pada korban tidak ditemukan bekas-bekas pembunuhan maka berarti zahirnya korban meninggal dunia dengan sendirinya.Kecuali dalam kasus korban yang diracuni, maka dapat dilakukan otopsi untuk membuktikan apakah korban meninggal karena racun atau tidak. Apabila ada darah keluar dari mata atau telinganya, maka dapat diberlakukan al-qasamah dan pembayaran diyat, karena biasanya darah tidak keluar bagian tubuh sepeti mata dan telinga kacuali disebabkan oleh tindakan penganiayaan ${ }^{33}$.

\footnotetext{
31Islamul Haq, “العلاقة السبيية في جريمة القتل (دراسة لغوية وحكمية)," Langkawi: Journal of The Association for Arabic and English 2, no. 1 (2016): 136-52.

${ }^{32} \mathrm{M}$ Salahuddin Almauludi, "Al-Qasamah Perspektif Hadis Nabi (Kajian Maudu 'i terhadap Pembuktian Tindak Pidana Pembunuhan)” (Universitas Islam Negeri Alauddin Makassar, 2017).

${ }^{33}$ Muhammad Rawwas Qal'ahji, "al-Mausu'ah al-Fiqhiyyah al-Muyassarah," Beirut: Dar al-Nafais, $j$ 2 (2000): 289.
} 
2. Adanya laust (petunjuk) yang mengarah kepada seseorang, yang kemudian bisa dianggap sebagai pelaku pembunuhan, misalnya korban ditemukan di halaman rumah musuhnya, syarat ini disebutkan oleh ulama Hanafiah.

3. Kemungkinan terjadinya pembunuhan dari yang tertuduh. Apabila pembunuhan tidak memungkinkan terjadi dari yang tertuduh karena factor usia atau sakit yang tidak memungkinkan ia melakukan pembunuhan, maka al qasamah tidak sah seperti dakwaan-dakwaan lainnya yang dibohongi oleh keberadaan panca indera. ${ }^{34}$

4. Pelaku pembunuhan tidak diketahui, apabila pelaku pembunuhan telah teridentifikasi, maka alqasamah tidak lagi diperlukan.

5. Korban adalah manusia, karena pembuktian al qasamah tidak berlaku pada kasus kematian binatang yang ditemukan dalam sebuah perkampungan.

6. Terdapat dakwaan yang diajukan oleh para wali korban ke pengadilan.Karena alqasamahmerupakan sumpah dan sumpah tidak dapat dilaksanakantanpa gugatan. Disyaratkan pula bahwa semua wali korban harus satu katadalam dakwaan tersebut. Apabila para wali korban tidak satu kata dalam dakwaan, maka alqasamah tidak dapat diberlakukan. Sebagai contoh jika wali korban yang pertama melaporkan dakwaan bahwa yang membunuh korban adalah si A secara sendiri, kemudian wali korban kedua melaporkan dakwaan bahwa yang membunuh korban adalah si B dan pembunuhan dilakukan secara sendiri, maka dakwaan tidak dapat diterima karena terdapat kontradiksi dalam dakwaan ${ }^{35}$.

7. Si tertuduh menyangkal dakwaan yang dujukan kepadanya, karena pada dasarnya sumpah dilakukan bagi orang yang menyangkal atau mengingkari tuduhan. Oleh karena itu jiak si tertuduh membenarkan tuduhan maka al qasamah tidak lagi diperlukan.

8. Adanya permintaan untuk dilakukannya al-qasamah. Karena al-qasamahmerupakan sumpah, sementara sumpah adalah hak si pendakwa, danhak seseorang dapat dipenuhi jika terdapat tuntutan, sebagaimana yang berlaku dalam sumpah-sumpah lainnya.

9. Tempat korban ditemukan merupakan sebuah tempat yang bertuan. Maksudnya termpat tersebut merupakan milik seseorang atau berada di bawah kekuasaan

\footnotetext{
${ }^{34} \mathrm{Al}$ Bassam dkk., Syarah bulughul maram.HIm. 207

${ }^{35} \mathrm{Abu}$ Abdillah Muhammad bin Al-Maqsidi dan Ahmad bin Abdul Hadi, "Ensiklopedi Hadits-Hadits Hukum, terj" (Suharjan dan Agus Ma'mun, Jakarta: Darus Sunnah Press, 2013).
} 


\section{Al-Qasamah}

seseorang.milik seseorang atau berada di bawah genggaman dan kekuasaan seseorang. Jikatidak, maka tidak ada al-qasamah dan tidak pula diyat. Contohnya: Apabila korban ditemukan di suatu daerah kosong (misalnya di tangah padang pasir atau di tengah hutan) bukan milik siapapun, maka jika letak tempat ditemukannya korban dekat dengan sebuah perkampungan yang sekiranya suara dapat terdengarkan dari perkampunga tersebut,maka penduduk yang ada di perkampungan tersebut wajib melakukan sumpah al qasamah.

Akan tetapi jika lokasi ditemukannya korban jauh dari perkampungan yang sekiranya suara tidak dapat didengarkan dari perkampungan ke tempat ditemukannya korban, maka tidak ada seorang pun yangterkena kewajiban al-qasamah dan tidak pula kewajiban diyat, akan tetapidiyat korban dibayarkan dengan menggunakan harta dari bait al-mal. Contoh lainnya Jika korban ditemukan di tengah sungai besarseperti Sungai kapuas, mahakam, dan Barito, maka tidak ada seorangpun yang terkena kewajiban al-qasamah dan tidak pula kewajiban diyat.Akan tetapi, diat korban dibayarkan dengan menggunakan harta dari baital-mal. Karena sungai besar bukan milik siapa pun dan tidak pula beradadi bawah genggaman dan kekuasaan siapa pun. Jika korban ditemukan ditepi sungai atau di sebuah pulau, maka penduduk yang ada di sekitar sungai atau pulau tersebut dikenaka kewajiban al-qasamah apabila suara dari tempat ditemukannya korban bisa terdengar di perkampungan tempat tinggal mereka ${ }^{36}$.

\section{Cara Pelaksanaan Al-Qasamah}

Ulama berbeda pendapat tentang siapa yang pertama kali bersumpah dalam pembuktian al-qasamah, apakah sumpah itu terlebih dahulu diucapkan oleh keluarga korban ataukah kepada pihak yang tertuduh. Menurut ulama mazhab Hanafiah, sumpah pertamakali diberikan kepada pihak yang tertuduh (terdakwa), dalam hal ini penduduk di mana korban pembunuhan ditemukan. Hal ini karena sumpah memang seharusnya diucapkan oleh pihak yang terdakwa yang telah ditunjuk oleh keluarga korban yang dituduh telah melakukan pembunuhan dengan mengatakan“demi Allah, saya tidak membunuhnya, dan saya tidak tahu siapa pelaku pembunuhan itu.". argumentasi ulama mazhab Hanafiah adalah hadist riwayat Bukhari dan Abu Dawud, yang artinya:

\footnotetext{
${ }^{36} \mathrm{Al}-$ Khin, al-Fiqh al-Manhaji 'ala Madhhab al-Imam al-Shafi i, j. 2 dan 3.HIm. 317
} 
"Bahwasanya Rasulullah berkata terlebih dahulu kepada orang Yahudi, "Lima puluh orang laki-laki dari kalian bersumpah”, akan tetapi merekatidak bersedia bersumpah, lantas beliau berkata kepada kepada orang-orangAnshar, "Tetapkanlah hak kalian (maksudnya, bersumpahlah kalian untukmenetapkan hak kalian yang kalian tuduhkan atas orang-orang Yahudiitu)', mereka berkata, "Apakah kami melakukan sumpah atas perkara yang ghaib wahai Rasulullah?", lantas Rasulullah menetapkan keharusanmembayar diyat atas orang-orang Yahudi, sebab korban pembunuhan ituditemukan di tengah-tengah mereka".

Sadangkan ulama lainnya seperti ulama dari kalangan mazhab Malikiyah, Syafi'iyah, Hanabilah serta Dawud Azh-Zhahiri, berpendapat bahwa yang pertama kali mengucapkan sumpah al-qasamah adalah keluarga dari korban pembunuhan. Mereka wajib mengucapkan sumpah sebanyak lima puluh kali, atau lima puluh orang yang bersumpah dan menyatakan bahwa terdakwalah yang telah membunuh korban. Pendapat mereka didasarkan pada hadist dari Sahl ibn Abi Hatsmah ra. di atas yang di dalamnya disebutkan, "Lalu Rasulullah bersabda,"Apakah kalian bersedia bersumpah dengan sumpah lima puluh orang di antarakalian? Jika bersedia, kalian berhak atas si pelaku pembunuhan saudara kalian".Yaitu, setiap wali di antara para wali korban itubersumpah di hadapan hakim dan pihak terdakwa serta dilakukan di masjidagung seusai shalat pada saat banyak orang berkumpul dengan ucapan sumpah,"Demi Allah Zat Yang tiada Tuhan selain Dia, sungguh korban dipukul oleh siFulan lalu korban pun mati”, atau, "Demi Allah Zat Yang tiada Tuhan selain Dia,sungguh korban dibunuh oleh si Fulan".

Sumpah al-qasamah juga disyaratkan harus mantap dan pasti yang menyatakan bahwa tersangka melakukan pembunuhan itu sendiri, atau bersama-sama dengan orang lain, ia melakukannya dengan sengaja atau karena kesalahan (tidak sengaja). Sumpah dari pihak keluarga korban dimulai dari ahli waris laki-laki sebagai ashabah dari korban. Apabila mereka telah bersumpah, maka hak yang wajib atas pembunuhan tersebut dibebankan kepada seluruh ahli waris. Jika mereka menarik sumpah, maka yang tertuduh harus bersumpah sebanyak lima puluh kali untuk membebaskan diri dari hukuman, apabil pihak tertuduh menolak untuk bersumpah maka dia wajib membayar diyat. Apabila pihak korban menarik sumpahnya dan mereka tidak menerima sumpah dari pihak tertuduh maka diyatnya dibayarkan dari baitul mal ${ }^{37}$.

\footnotetext{
${ }^{37} \mathrm{Al}$ Bassam dkk., Syarah bulughul maram.HIm. 208
} 


\section{Al-Qasamah}

Implikasi hukum dari pelaksanaanal-qasamah adalah sesuai kesepakatan para ulama yaitu diwajibkannya diat, apabila kasus pembunuhannya adalah pembunuhan semi sengaja atau pembunuhan tersalah (tidak sengaja). Jika pembunuhan tersebut merupakan pembunuhan sengaja, ulama berbeda pendapat mengenai hukuman yang dijatuhkan. Menurut Imam Malik, dan qaul qadim dari mazhab Syafi'i, serta Imam Ahmad, hukuman yang dijatuhkan adalah hukuman diyat, baik pembunuhnya sengaja maupun tidak sengaja.

\section{Kesimpulan}

Perpaduan konsep antara hukum pidana di Indonesia dan Pidana Islam/Jinayah, termasuk dalam pembuktian pidana pembunuhan seperti al-qasamah ini, sebenarnya dapat dilakukan dengan menggunakan teori objektifikasi. Dengan teori ini tadi, nilainilai yang terkandung dalam Hukum Pidana Islam diupayakan untuk dapat diinternalisasikan kedalam hukum pidana yang berlaku di Indonesia. ${ }^{38}$ Karena secara prinsip, ada kesamaan antara pidana umum dan pidana Islam, Syariat Islam sangat menghormati kedudukan jiwa manusia, bahkan jiwa (nyawa) menusia berada pada derajat yang sangat tinggi dalam Islam, dalam syariat Islam terdapat prinsip yang merupakan salah satu maqashid syariah kategori dharuriyat yaitu hifdzu al nafs (menjaga jiwa). Salah satu prinsip jaminan terhadap jiwa, jiwa manusia tidak boleh hilang begitu saja tanpa ada imbalan, metode pembuktian dengan al-qasamah merupakan salah satu metode yang patut dipertimbangkan, terlebih metode ini telah dimplementasikan pada zaman Rasulullah SAW., meskipun awalnya berasal dari zaman jahiliyah. Hikmah Islam mengakui pembuktian al-qasamah adalah untuk melindungi jiwa manusia supaya korban pembunuhan yang tidak ada saksinya tidak diabaikan begitu saja. Meskipun demikian hukuman tindak pindana yang didasarkan pada pembuktian al-qasamah harus dibatasi, yaitu hukumannya tidak sampai kepada hukuman qisas melinkah hanya dengan hukuman diyat.

\section{Daftar Pustaka}

Ahmad Erani Yustika. Ekonomi Politik. Yogyakarta: Pustaka Pelajar, 2011.

${ }^{38}$ Marfuatul Latifah, "UPAYA TRANSFORMASI KONSEP JARIMAH QISASH-DIYAT PADA HUKUM POSITIF MELALUI RUU KUHP" 2, no. 1 (2011): 22. 
Al-Sheikh, Abdullah bin Muhammad bin Abdurahman bin Ishaq. Tafsir Ibnu Katsir. Vol. II. Bogor: Pustaka Imam Syafii, 2000.

Arfan, Abbas. "Maqasid Al-Syariah Sebagai Sumber Hukum Islam, Analisis Terhadap Pemikiran Jasser Auda." Al-Manahij 07, no. 01 (Juli 2013).

Asshiddiqie, Jimly, dan M. Ali Safa'at. Teori Hans Kelsen Tentang Hukum. Jakarta: Konpress, 2014.

Auda, Jasser. Al-Maqashid Untuk Pemula. Diterjemahkan oleh Ali Abdelmon`im. Yogyakarta: SUKA Press, 2013.

- - - Membumikan Hukum Islam Melalui Maqashid Syariah. Diterjemahkan oleh Rosidin dan 'Ali 'Abd el-Mun'im. Bandung: Mizan, 2015.

Badruzaman, Abad. "Dari 'Illah Ke Maqasid: Formula Dinamisasi Hukum Islam Di Era Kekinian Melalui Pengembangan Konsep Maqasid." Ijtihad 14, no. 01 (Juni 2014).

Balakina, Olga, dan Donato Masciandaro. Banking Secrecy And Global Finance. New York: Palgrave Macmillan, 2015.

Chaikin, David. "Policy And Fiscal Effects Of Swiss Bank Secrecy." REVENUE LAW JOURNAL 15, no. 01 (Januari 2005).

Faizin, Mu'adil. "Analisis Maqāșid Asy-Syarī’ah Terhadap Prinsip Kerahasiaan Bank Dan Akses Informasi Perpajakan." Masters, UIN SUNAN KALIJAGA YOGYAKARTA, 2018.

Faizin, Mu'adil. "Hak Asasi Manusia Dalam Pemikiran Yusuf Qaradhawi." Al-Mazahib 5, no. 1 (1 Juni 2017).

Faizin, Mu'adil. "The Sharia Law Politics Law in Indonesia Year 2008-2017." Adzkiya: Jurnal Hukum dan Ekonomi Syariah 5, no. 2 (1 September 2017).

Gazali, Djoni S., dan Rachmadi Usman. Hukum Perbankan. Jakarta: Sinar Grafika, 2012.

G.P, M.Arskal Salim. Etika Intervensi Negara Perspektif Etika Politik Ibnu Taimiyah. Jakarta: Logos, 1998.

Hakim, Muhammad Lutfi. "Pergeseran Paradigma Maqasid Al-Syari'ah: Dari Klasik Sampai Kontemporer." Al-Manahij 10, no. 01 (Juni 2016).

Hasan, Mufti. "Mekanisme Penyelesaian Ayat Kontradiktif Berbasis Maqasid AlShariah: Studi Terhadap Ayat Perkawinan Beda Agama." THEOLOGIA 28, no. 01 (Juni 2017). 
Idris, Miftah. "Kerahasiaan Bank Suatu Tinjauan Dalam Aturan Hukum Perbankan Syariah Di Indoesia." Al-Amwal : Journal of Islamic Economic Law 1, no. 1 (20 Mei 2019).

Jundiani. Pengaturan Hukum Perbankan Syariah Di Indonesia. Malang: UIN Malang Press, 2009.

Kasmir. Dasar-Dasar Perbankan. Jakarta: Raja Grafindo, 2012.

Khariri. "Penalaran Hukum Islam (Upaya Mensinergikan Metode al-Tsawabit dan alMutaghayyirat)." Al-Manahij 10, no. 01 (Juni 2016).

Knobel, Andres, dan Markus Meinzer. "The End Of Bank Secrecy? Bridging The GapTo Effective Automatic Information Exchange." Tax Justice Network, 10 November 2014.

Mahfud MD", Moh. Membangun Politik Hukum, Menegakkan Konstitusi. Jakarta: Rajawali Pers, 2010.

Maulidi. "Metodologi ljtihad Fikih Kontemporer (Telaah Atas Pemikiran Yusuf AlQaradawi)." Al-Manahij 8, no. 01 (Januari 2014).

Maulidi, Maulidi. "Paradigma Progresif dan Maqashid Syariah: Manhaj Baru Menemukan Hukum Responsif." Asy-Syir'ah Jurnal Ilmu Syari'ah dan Hukum 49, no. 2 (2015).

Muttaqin, Muhammad Ngizzul, dan Iffatin Nur. "Menelusuri Jejak Maqashid Syari'ah Dalam Istinbath Hukum Imam Hambali." AHKAM 07, no. 01 (Juli 2019).

PERPU No. 1 Tahun 2017 Tentang Akses Informasi Keuangan Untuk Kepentingan Perpajakan, (2017).

Rani, Marnia. "Perlindungan Otoritas Jasa Keuangan Terhadap Kerahasiaan Dan Keamanan Data Pribadi Nasabah Bank." SELAT 2, no. 1 (Oktober 2014).

- - . "Perlindungan Otoritas Jasa Keuangan Terhadap Kerahasiaan Dan Keamanan Data Pribadi Nasabah Bank" 2, no. 1 (2014).

Safriadi, Safriadi. "Kontribusi Ibn 'Āsyūr Dalam Kajian Maqāsid Al-Syarī'ah." Jurnal Ilmiah Islam Futura 15, no. 2 (1 Februari 2016).

Samsul Anwar. "Teori Pertingkatan Norma Dalam Ushul Fikih." Asy-Syir'ah 50, no. 01 (Juni 2016).

Samuddin, Rapung. Fiqih Demokrasi. Jakarta: GOZIAN Press, 2013.

Surono, Agus. Fiksi Hukum Dalam Pembuatan Peraturan Perundang-Undangan. Jakarta: UAI, 2013. 
Sutendi, Adrian. Hukum Pajak. Jakarta: Sinar Grafika, 2011.

Syarifuddin, Amir. Ushul Figh Jilid 2. Revisi. Jakarta: Kencana, 2014.

Taimiyah, Ibn. Siyasah Syar'iyah. Diterjemahkan oleh Rofi' Munawar. Surabaya: Risalah Gusti, 2005.

UU No. 21 Tahun 2008 tentang Perbankan Syariah (2008).

UU No. 9 Tahun 2017 Tentang Penetapan PERPU No. 1 Menjadi Undang-Undang (2017).

UU No. 28 Tahun 2007 Tentang Perubahan Ketiga Atas UU No. 6 Tahun 1983 Tentang Ketentuan Umum Dan Tata Cara Perpajakan (2007).

Wahyudi, Yudian. Hukum Islam Antara Filasafat Dan Politik. Yogyakarta: Pesantren Nawasea Press, 2015.

Yaqin, Ainol. "Revitalisasi Maqashid Al-Syari'ah dalam Istinbath Hukum Islam: Kajian atas Pemikiran Muhammad Al-Thahir Ibnu 'Asyur." Asy-Syir'ah Jurnal IImu Syari'ah dan Hukum 50, no. 2 (2016). 